\title{
Identification of Bacteria Infecting Seedlings of Mung Bean Used in Rooting Bioassays
}

\author{
R.R. Tripepi and M.W. George \\ Plant Science Division, University of Idaho, Moscow, ID 838434196 \\ Additional index words. Vigna radiata, rooting bioassay, root initiation, Curtobacterium flaccumfaciens ssp. \\ flaccumfaciens, Pseudomonas syringae pv. syringae
}

\begin{abstract}
Seeds of 'Berken' mung bean [Vigna radiata (L.) R. Wilcz.] were surface-sterilized with NaOCl and then either aerated 24 hours before sowing (routine procedure), planted immediately after the NaOCl treatment, or treated with hot cupric acetate and antibiotics before planting. Nine- or 10-day-old seedlings were used in rooting bioassays. Up to $10 \%$ of the seedlings and $17 \%$ of the cuttings had collapsed upper stems or wilted leaves. None of the seed treatments completely eliminated the pathogen, but the combination of hot cupric acetate plus antibiotics reduced the quantity of diseased cuttings to $3.3 \%$. A white and two yellow-pigmented (Y1 and Y2) bacteria were isolated from diseased cuttings and used in subsequent pathogenicity tests. The Y2 strain was nonpathogenic. Stems of plants inoculated with the white strain turned brown and collapsed 2 days after inoculation, whereas leaves of plants inoculated with the Y1 strain wilted after 7 days. Electron microscopy, fatty acid analysis, and standard biochemical and physiological tests were used to identify the white strain as Pseudomonas syringae pv. syringae van Hall and the Y1 strain as Curtobacterium flaccumfaciens ssp. flaccumfaciens (Hedges) Collins and Jones. These results emphasize that seeds of mung bean should be checked for seedborne pathogens to avoid experimental artifacts.
\end{abstract}

Mung bean is used as a model system for physiological studies on plant mitochondria (Musgrave et al., 1988) and adventitious root initiation and development (Blazich and Heuser, 1979a; Tripepi et al., 1983; Norcini et al., 1985). The mung bean rooting bioassay (Blazich and Heuser, 1979b) is often used to determine the root-promoting ability of growth regulators or plant extracts (Kling and Meyer, 1983; Kling et al., 1988). An important requirement of this bioassay is to limit rooting variability from factors other than experimental treatments (Bassuk and Howard, 1981).

Several studies have shown that external factors can affect adventitious root formation in cuttings of mung bean. Water quality (Blazich and Heuser, 1979b; Duvall and Krul, 1985), age of the cuttings (Bassuk and Howard, 1981; Blazich and Heuser, 1979b), cotyledons (Bassuk and Howard, 1981), density of cuttings in the rooting medium, and parental genotype (Duvall and Krul, 1985) can cause rooting variability among cuttings.

In our work with the rooting bioassay, seedlings and cuttings of mung bean displayed symptoms of collapsed upper stems, wilted leaves, necrotic spots on leaves, or various combinations of these abnormalities (Fig. 1). Others (Blazich and Heuser, 1979b; J. Norcini, personal communication) have also encountered similar difficulties with seedlings and cuttings of mung bean or reported that cuttings that lacked roots or rooted poorly often had lesions on their leaves. No information is available describing stem or leaf problems of mung beans used for rooting bioassays. Therefore, we document and identify the cause of leaf lesions and stem wilting in mung bean.

\section{Materials and Methods}

Seed treatments. Seeds of 'Berken' mung bean were purchased from a commercial distributor; damaged seeds were dis-

Received for publication 22 Feb. 1990. Idaho Agricultural Experiment Station Research Paper no. 9078. We thank N. Schaad, D. Gross, and R. Durbin for technical advice and for supplying known strains of Curtobacterium flaccumfaciens subspecies, Pseudomonas syringae pathovars, and Xanthomonas campestris pv. campestris. Technical assistance of Angela dela Cruz and Jon Olson is also acknowledged. Tbe cost of publishing this paper was defrayed in part by the payment of page charges. Under postal regulations, this paper therefore must be hereby marked advertisement solely to indicate this fact.

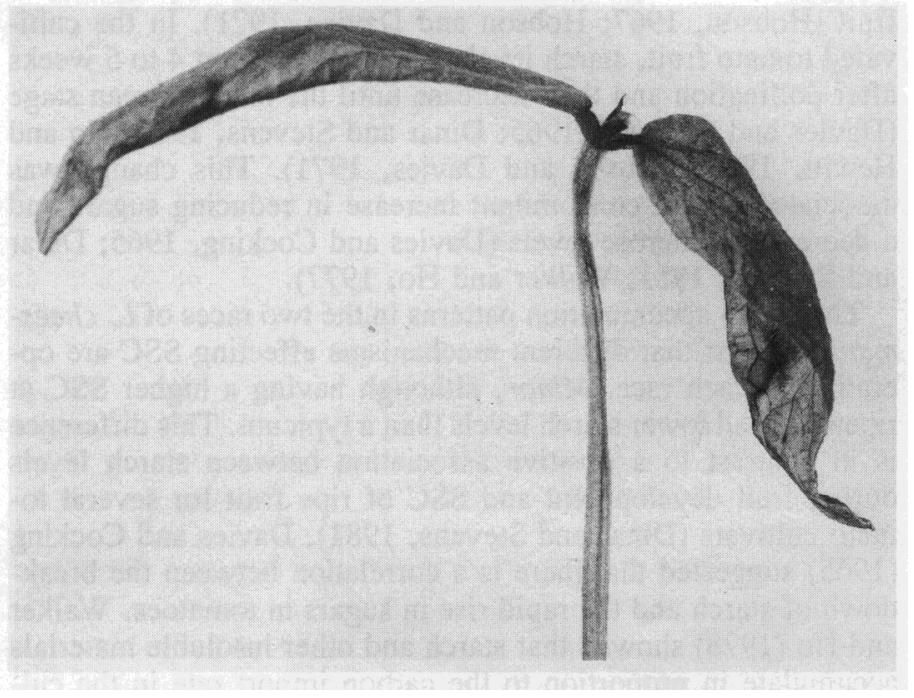

Fig. 1. Typical disease symptoms on a mung bean seedling included a collapsed upper stem and wilted leaves.

carded before treatment. Seeds were surface-sterilized with $0.5 \%$ $\mathrm{NaOCl}$ for 10 min and either: 1) rinsed with tap water and aerated $24 \mathrm{~h}$ in tap water before sowing, 2) rinsed with sterile distilled water and sown immediately, or 3) rinsed with sterile water, soaked for $20 \mathrm{~min}$ at $52 \mathrm{C}$ in a solution containing $0.25 \%$ (w/v) cupric acetate dissolved in $0.005 \mathrm{~N}$ acetic acid (Schaad et al., 1980), rinsed, placed in a sterile solution of the antibiotics tetracycline (10 mg.liter $\left.{ }^{-1}\right)$ and cephalexin $\left(10 \mathrm{mg} \cdot \mathrm{liter}^{-1}\right)$ for 30 rein, rinsed, and sown immediately. Only sterilized distilled water was used in treatments 2 and 3 . In addition, all glassware used in treatments 2 and 3 was autoclave.

Seeds were sown in perlite in $26 \times 26 \times 6$-cm (4-liter) plastic trays. Trays were soaked in $0.05 \% \mathrm{NaOCl}$ and rinsed before use. Seeds were germinated and grown in a growth chamber maintained at $27 / 23 \pm 1 \mathrm{C}$ during the 16 -h day/8-h night cycle. During the day, photosynthetic photon flux of 180 $\mu \mathrm{mol} \cdot \mathrm{s}^{-1} \cdot \mathrm{m}^{-2}$ was provided by a combination of cool-white fluorescent and incandescent lamps. Regardless of the type of experiment, all trays were watered daily with $500 \mathrm{ml}$ of tap water, and special care was taken to avoid wetting the cotyle- 
dons, epicotyls, and leaves of emerged seedlings. Seeds were grown for 9 days before the number of infected seedlings were recorded. To compensate for the shorter seed treatments with the second and third procedures, seedlings were grown for 10 days ( 1 extra day) before the number of diseased plants was recorded. About 600 seeds were aerated $24 \mathrm{~h}$ in each of three experiments for treatment 1 . Eight groups of beans (four replicates of $\approx 100$ seeds in two separate experiments) that received seed treatments 2 and 3 were treated and sown at the same time. Likewise, rooting bioassays with plants grown from seeds receiving these two treatments were conducted.

Bioassay procedure. Only healthy seedlings were selected for rooting bioassays. Off-type plants, those with short epicotyls, split hypocotyls, or disease symptoms, were discarded. Seedlings were cut and handled according to procedures described by Tripepi et al. (1983). Uniform cuttings were made from 9- or 10-day-old seedlings, corresponding to the seed treatment used. Ten cuttings were selected at random and placed in shell vials containing $1 \mathrm{ml}$ of an 1H-indole-3-butyric acid (IBA) solution or $10 \mathrm{~mm}$ K-phosphate buffer, $\mathrm{pH}$ 7.0. The concentration of IBA used in the treatments ranged from $0.1 \mu \mathrm{M}$ to $1000 \mu \mathrm{M}$ in K-phosphate buffer. Vials were arranged in a completely randomized design in the growth chamber. Each treatment was replicated three times, and each experiment was completed twice.

Pathogen isolation. Symptomatic stem or leaf tissue was excised from three diseased cuttings of mung bean used previously in a rooting bioassay. Suspected pathogens were isolated according to procedures described by Schaad (1988). Single colonies of three suspected pathogens were transferred to medium 523 (Kado and Heskett, 1970) to ensure that pure bacterial colonies were obtained.

Pathogenicity trials. The three bacterial strains were tested for pathogenicity on seedlings of mung bean. Seeds of mung bean were treated with hot cupric acetate plus antibiotics and sown immediately. After 10 days, seedlings in each tray were evaluated and off-types were discarded so that each tray contained 75 plants. Seedlings in each tray were grouped into units of 10 plants for stem inoculations and five for leaf inoculations. Each treatment was applied to one unit of plants per tray and four trays were used in each experiment. Thus, a total of 40 seedlings were stem-inoculated and 20 seedlings were leaf-inoculated per treatment. This experiment was completed three times. During the third experiment, seedlings were grown in a glasshouse. Photoperiod, temperature, and watering regimes were similar to those used for plants in the growth chamber.

Bacteria used as inocula were grown in liquid medium 523 for $18 \mathrm{~h}$ at $23 \mathrm{C}$. The suspensions were diluted as described by Vidaver and Davis (1988) with $1.2 \mathrm{mM} \mathrm{KH}_{2} \mathrm{PO}_{4}(\mathrm{pH}=7.2)$ and then further diluted to $\approx 1 \times 10^{6}$ colony-forming units (cfu)/ $\mathrm{ml}$ of suspension.

Treatments were randomly assigned to each group of seedlings and included: 1) white strain, 2) Y1 strain, 3) Y2 strain, 4) sterile $1.2 \mathrm{mM} \mathrm{KH}_{2} \mathrm{PO}_{4}$ solution, and 5) Xanthomonas campestris pv. campestris (Pammel) Dowson (strain B-24). Xanthomonas campestis pv. campestris is a nonpathogenic bacterium of bean and was used as a negative control. Sterile needles and syringes filled with treatment suspensions were used to pierce stems $\approx 2 \mathrm{~mm}$ below the apex, and a second wound was made $\approx 4 \mathrm{~mm}$ below the first. A small drop of inoculum was left over each wound. Leaves were wounded in four places on the midsection of their blades, and a drop of inoculum was left over each wound. Only one leaf on selected plants was wounded. After inoculation, seedlings were returned to the growth cham- ber. Seedlings were evaluated for disease symptoms 9 days after inoculation, and the suspected pathogens were reisolated and characterized from symptomatic tissue to fulfill Koch's postulates.

The effect of inoculum concentration on symptom expression was also tested for the white and Y1 strains. A total of 40 seedlings were stem-inoculated with various concentrations of each strain; the populations ranged from $5.7 \times 10^{3}$ to $2.2 \times$ $10^{6} \mathrm{cfu} / \mathrm{ml}$. This experiment was completed twice.

Pathogen identification. Since the Y2 strain consistently failed to produce any disease symptoms in the pathogenicity tests, only the white and the Y1 strains were identified. Both bacteria were initially characterized by the following tests: gram-reaction (Schaad, 1988), electron microscopy for presence of flagella (Schaad, 1988), anaerobic growth capability (Schaad, 1988), and fatty acid analyses completed by Microbial ID, Newark, Del. (Roy, 1988).

The white bacterium was characterized further by the following tests: production of fluorescent pigment on King's medium B (Hildebrand et al., 1988); levan production (Hildebrand et al., 1988); oxidase reaction (Schaad, 1988); potato rot (Fahy and Hayward, 1983); tobacco hypersensitivity (Fahy and Hayward, 1983); ability to use mannitol, inositol, sorbitol, and Llactate (Fahy and Hayward, 1983; Hildebrand et al., 1988); bean pod test for halo blight (Fahy and Hayward, 1983); syringomycin producing using Geotrichum candidum as the test organism (Gross and DeVay, 1977); and reaction with a DNA probe for the phaseolotoxin gene (Schaad et al., 1989). Known strains of Pseudomonas syringae pathovars were used as comparison organisms for these tests.

The Y1 strain was further characterized by pigment color on nutrient broth yeast extract (NBY) agar (Vidaver and Davis, 1988) and its ability to metabolize fumarate (Dye and Kemp, 1977). Known strains of Curtobacterium flaccumfaciens (Hedges) Collins and Jones subspecies were used as comparison organisms for these two tests.

\section{Results}

Seed treatment and bioassay results. Infected seedlings of mung bean were present regardless of the seed treatment. When seeds of mung bean were aerated $24 \mathrm{~h}$ (treatment 1 ), up to $10 \%$ of the seedlings were diseased, based on visual symptoms (Fig. 1). Only $2 \%$ to $4 \%$ of the seedlings from seeds that lacked an aeration treatment or that received the hot cupric acetate plus antibiotics treatment were diseased (Table 1).

Some seedlings that appeared healthy and that were used for cuttings later showed disease symptoms during rooting bioassays, and a few diseased cuttings eventually died. When seeds were treated in the usual manner (treatment 1 ), $7 \%$ to $17 \%$ (mean $\pm \mathrm{SE}=12.2 \% \pm 2.9 \%$ ) of the cuttings became diseased. Although this percentage of diseased cuttings was similar to that of seeds that received treatment 2 (no aeration), the combination of hot cupric acetate plus antibiotics (treatment 3) resulted in 3.7 times fewer diseased cuttings (Table 1). Diseased cuttings were randomly distributed among the IBA and buffer treatments, regardless of the seed treatment (data not presented).

Pathogen isolation. Three types of bacteria were isolated from symptomatic stem tissue of diseased cuttings of mung bean. One of the bacteria was white while growing on NBY, whereas the other two were yellow. We were unable to isolate any bacteria from diseased leaf tissue.

Pathogenicity trials. Only the white and Y1 strains produced disease symptoms on inoculated seedlings. For plants whose 
Table 1. Proportion and overall percentage of seedlings and cuttings of mung bean with disease symptoms in two experiments.

\begin{tabular}{|c|c|c|c|c|c|c|}
\hline \multirow{3}{*}{$\begin{array}{c}\text { Seed } \\
\text { treatment }\end{array}$} & \multicolumn{3}{|c|}{ Seedlings } & \multicolumn{3}{|c|}{ Cuttings } \\
\hline & \multicolumn{2}{|c|}{ Experiment } & \multirow{2}{*}{$\begin{array}{c}\text { Mean of } \\
\text { Expts. } \\
1 \text { and } 2 \\
(\% \pm \mathrm{SE})\end{array}$} & \multicolumn{2}{|c|}{ Experiment } & \multirow{2}{*}{$\begin{array}{c}\text { Mean of } \\
\text { Expts. } \\
1 \text { and } 2 \\
(\% \pm \mathrm{SE})\end{array}$} \\
\hline & 1 & 2 & & 1 & 2 & \\
\hline $\begin{array}{l}\text { No aeration } \\
\text { Hot Cu acetate }\end{array}$ & $11 / 419$ & $18 / 398$ & $3.6 \pm 1.0$ & $21 / 120$ & $13 / 120$ & $14.2 \pm 3.3$ \\
\hline+ antibiotics & $13 / 398$ & $2 / 379$ & $2.0 \pm 1.3$ & $2 / 120$ & $6 / 120$ & $3.3 \pm 1.6$ \\
\hline
\end{tabular}

stems were inoculated with the white organism, stems started to turn brown and collapse only 2 days after inoculation with a bacterial concentration of $2.5 \times 10^{5} \mathrm{cfu} / \mathrm{ml}$. By 9 days, almost $80 \%$ of these seedlings exhibited stem disease symptoms (Table 2 ). Reddish brown necrotic areas also appeared on the leaves of these seedlings, and leaves of severely affected plants became desiccated. Leaves of seedlings that were stem-inoculated with Y1 strain at a concentration of $3.1 \times 10^{6} \mathrm{cfu} / \mathrm{ml}$ began to wilt 7 days after treatment. Stems of these plants remained healthy throughout the experiment (Table 2). By 9 days, half of the Y1 stem-inoculated seedlings had wilted and shriveled leaves. Seedlings whose stems were injected with the Y2 strain, $X$. campestris pv. campestris, or the buffer lacked disease symptoms.

Only the white and Y1 strains caused disease symptoms when injected into the leaves (Table 3). Leaf inoculations with the white strain consistently produced brown necrotic areas around injection wounds. In "contrast, stems were unaffected by leaf injections of the white strain. For the Y1 leaf inoculations, about half of the inoculated leaves wilted. Leaves inoculated with the Y2 strain, X. campestris pv. campestris, or the buffer remained healthy throughout the experiment.

The Y1 pathogen was consistently reisolated from symptomatic leaf tissue and healthy-looking stem tissue of stem-inoculated seedlings. Reisolation of the white strain was more difficult. About half of the reisolations from symptomatic stem tissue on stem-inoculated seedlings produced the white pathogen. All of the reisolations for the white strain from leaf-inoculated tissue were unsuccessful.

Disease symptoms on inoculated seedlings developed at the same frequency in the glasshouse and growth chamber (Tables 2 and 3). Although the expression of leaf symptoms was slightly lower for glasshouse seedlings that were stem-inoculated with the Y1 strain (Table 2), the percentages of disease among leafinoculated plants grown in the glasshouse or growth chamber were similar (Table 3 ).

As few as $5.7 \times 10^{3} \mathrm{cfu} / \mathrm{ml}$ for the white strain and $2.2 \times$
$10^{4} \mathrm{cfu} / \mathrm{ml}$ for Y1 were necessary for development of disease symptoms within 10 days of inoculation. The number of seedlings affected was directly influenced by initial inoculum density. The higher the concentration of inoculum, the greater the number of diseased seedlings (data not presented).

Pathogen identification. The white strain was a gram-negative, aerobic, rod-shaped bacterium with polar flagella. Fatty acid analysis indicated that the unknown white bacterium had the highest similarity index for Pseudomonas syringae (0.880) and $P$. syringae pv. morsprunorum (0.880). The next highest similarity index was for $P$. syringae pv. tabaci $(0.853)$. The white strain produced a green diffusible, fluorescent pigment on King's medium B, produced levan, and caused a hypersensitive reaction in tobacco, but failed to produce oxidase and potato rot. These results supported the fatty acid analysis data, indicating the white bacterium was a pathovar of Pseudomonas syringae. Results of the other tests (Table 4) indicated that the white organism was the syringae pathovar (Fahy and Lloyd, 1983; Hildebrand et al., 1988).

The Y1 pathogen was a gram-positive, aerobic bacterium with lateral flagella. Fatty acid analysis showed a very high similarity for Curtobacterium flaccumfaciens ssp. flaccumfaciens (0.841). The similarity index for $C$. flaccumfaciens ssp. betae was 0.702 and 0.588 for $C$. flaccumfaciens subspecies oortii. Colonies of the Y1 strain and $C$. flaccumfaciens ssp. were yellow when grown on NBY media. Only the Y1 strain and C. flaccumfaciens ssp. flaccumfaciens used fumarate as a carbon source, indicating that Y1 was $C$. flaccumfaciens ssp. flaccumfaciens (Dye and Kemp, 1977).

\section{Discussion}

Curtobacterium flaccumfaciens ssp. flaccumfaciens and Pseudomonas syringae pv. syringae were isolated and identified as the pathogens that caused the disease symptoms of mung beans. These pathogens were apparently seedborne, since up to $10 \%$ of the seedlings that grew from surface-sterilized seeds became diseased within 9 days of sowing. Even though the

Table 2. Proportion and overall percentage of stem-inoculated seedlings of mung bean with disease symptoms in three experiments.

\begin{tabular}{|c|c|c|c|c|c|c|c|c|}
\hline \multirow[b]{3}{*}{ Isolate $^{z}$} & \multicolumn{4}{|c|}{ Stem symptoms } & \multicolumn{4}{|c|}{ Leaf symptoms } \\
\hline & \multicolumn{2}{|c|}{ Growth chamber } & \multirow{2}{*}{$\begin{array}{c}\begin{array}{c}\text { Glass- } \\
\text { house }\end{array} \\
\text { (Expt. 3) }\end{array}$} & \multirow{2}{*}{$\begin{array}{c}\text { Mean of } \\
\text { all } \\
(\% \pm S E)\end{array}$} & \multicolumn{2}{|c|}{ Growth chamber } & \multirow{2}{*}{$\begin{array}{c}\begin{array}{c}\text { Glass- } \\
\text { house }\end{array} \\
\text { (Expt. 3) }\end{array}$} & \multirow{2}{*}{$\begin{array}{c}\text { Mean of } \\
\text { all } \\
(\% \pm \text { SE })\end{array}$} \\
\hline & (Expt. 1) & (Expt. 2) & & & (Expt. 1) & (Expt. 2) & & \\
\hline White & $30 / 40$ & $36 / 40$ & $29 / 40$ & $79.2 \pm 4.2$ & $16 / 40$ & $34 / 40$ & $29 / 40$ & $66.7 \pm 6.8$ \\
\hline Y1 & $0 / 40$ & $0 / 40$ & $0 / 40$ & 0.0 & $22 / 40$ & $25 / 40$ & $14 / 40$ & $50.0+4.4$ \\
\hline
\end{tabular}

IIsolate Y2, X. cumpestris pv. cumpestris, and sterile buffer induced no symptoms in any of the three experiments; $\mathrm{n}=40$ for all three. 
Table 3. Proportion and overall percentage of leaf-inoculated seedlings of mung bean with leaf disease symptoms in three experiments.

\begin{tabular}{lccccr} 
Isolate & \multicolumn{2}{c}{\begin{tabular}{c} 
Growth chamber \\
\cline { 2 - 3 }
\end{tabular}} & $\begin{array}{c}\text { Glass- } \\
\text { house }\end{array}$ & $\begin{array}{c}\text { Mean of } \\
\text { all }\end{array}$ \\
\hline White & $20 / 20$ & $20 / 20$ & & $15 / 15$ & $100.0 \pm 0.0$ \\
Y1 & ND $^{y}$ & $11 / 20$ & & $10 / 20$ & $52.5+9.2$ \\
\hline
\end{tabular}

${ }^{2}$ Isolate Y2, X. campestris pv. campestris, and sterile buffer induced no symptoms in any of the three experiments; $n=20$ for all three. ${ }^{y} \mathrm{ND}=$ not determined.

Table 4. Physiological and biochemical reactions of the white strain from mung bean and known pathovars of Pseudomonas syringae.

\begin{tabular}{|c|c|c|c|c|c|}
\hline \multirow[b]{2}{*}{ Test } & \multicolumn{5}{|c|}{ Bacteria tested ${ }^{z}$} \\
\hline & White & $\operatorname{Syr}^{x}$ & Mors & $\mathrm{Tab}$ & Phas \\
\hline Bean pod test & $-y$ & - & ND & ND & + \\
\hline DNA probe & - & - & ND & ND & $+w$ \\
\hline Syringomycin & + & $t^{v}$ & - & ND & ND \\
\hline \multicolumn{6}{|l|}{ Utilization of: } \\
\hline Mannitol & + & + & + & + & - \\
\hline Inositol & + & + & + & + & - \\
\hline Sorbitol & + & + & + & + & - \\
\hline L-lactate & + & +4 & - & - & ND \\
\hline
\end{tabular}

${ }^{2}$ Bacteria abbreviations: White $=$ white strain; Syr $=$ P.s. pv. syringae; Mors = P.s. pv. morsprunorum; Tab = P.s. pv. tabaci; Phas = P.s. pv. phaseolicola.

+ is a positive result; - 'is a negative result; ND = not determined. ${ }^{\mathrm{x}}$ Strain BR-2 was used for all tests except syringomycin and L-lactate tests.

"Many different strains were used.

"Strain B-301D, a known syringomycin producer, was tested.

"Strain C-454 was tested.

numbers of diseased seedlings were similar for seeds that lacked an aeration treatment or those receiving the hot cupric acetate plus antibiotics treatment, the number of diseased cuttings was greatly reduced by the latter treatment (Table 1). None of the seed treatments completely eliminated the diseases from seedlings or cuttings. We purchased seeds from another national supplier and also found them to be infected, indicating that contamination of mung bean seeds may be common among domestically produced seeds.

Curtobaccerium flaccumfaciens ssp. flaccumfaciens causes a vascular wilt disease in mung bean and several species of Phaseolus (Moffett et al., 1983). The pathogen is usually seedborne, and it can persist for a long time in infected seeds (Zaumeyer and Thomas, 1957). This pathogen is also difficult to eradicate from infected seeds, and the usual control method is to use disease-free seeds (Zaumeyer and Thomas, 1957).

To our knowledge, this work is the first report of $P$. syringae pv. syringae causing a disease of mung bean. This pathogen causes discolored or necrotic spots on various plant parts, dieback of shoots, or cankers on twigs and branches of a wide range of plant species, including several species of Phaseolus and Vigna (Bradbury, 1984). Seedlings and cuttings of mung bean in our study had collapsed stems, necrotic spots on leaves, or both (Fig. 1). Perhaps P. syringae pv. syingae also caused necrotic lesions on leaves of mung bean cuttings used by Blazich and Heuser (1979b). Pseudomonas syringae pv. syringae can be present on a host without causing disease until some condition, including changes in a plant's physiological status, becomes favorable for disease expression (Daub and Hagedorn,
1981). This phenomenon may explain why the incidence of disease was greater for cuttings than for seedlings (Table 1). For beans, one source of the pathogen is in infected seeds, and use of disease-free seeds is the only effective control (Zaumeyer and Thomas, 1957).

Diseased seeds of mung bean can cause rooting variability between cuttings during bioassays. Several problems may arise with the use of contaminated mung beans. First, statistical design can be compromised if plants or cuttings are killed by disease during an experiment. Even though our best seed treatment reduced the proportion of diseased cuttings to $\approx 3 \%$ (Table .1), this amount of contamination was still unacceptable for statistical analyses of the data for treatment effects. Another, and perhaps more subtle problem, is the creation of artifacts or biased results through the use of contaminated seeds. In our experiments, some diseased cuttings had short roots, fewer roots than normal, or completely lacked roots. Other cuttings appeared healthy but had fewer or shorter roots compared to those receiving the same treatment. Relatively large populations of $P$. syringae pv. syringae can exist on susceptible bean plants while the host's foliage remains symptomless (Daub and Hagedorn, 1981). Perhaps the pathogen was present in cuttings with poor rooting responses, but these plants lacked detectable disease symptoms.

All microbial contamination of seedlings and cuttings of mung bean should be eliminated, since the presence of microbes and their metabolizes may inhibit root initiation in cuttings during rooting bioassays (Blazich and Heuser, 1979b). However, our seed treatments failed to completely eradicate bacterial pathogens contaminating seeds used for rooting bioassays. Therefore, seeds of mung bean purchased from commercial distributors need to be tested for bacterial pathogens, and only those lots free from contamination should be used in experiments.

\section{Literature Cited}

Bassuk, N.L. and B.H. Howard. 1981. Factors affecting the use of mung bean (Vigna radiata L. Wilczek) cuttings as a bioassay for root-promoting substances. J. Hort. Sci. 56:295-300.

Blazich, F.A. and C.W. Heuser. 1979a. A histological study of adventitious root initiation in mung bean cuttings. J. Amer. Soc. Hort. Sci. 104:63-67.

Blazich, F.A. and C.W. Heuser. 1979b. The mung bean rooting bioassay: A reexamination. J. Amer. Soc. Hort. Sci. 104:117-120.

Bradbury, J.F. 1984. Guide to plant pathogenic bacteria. Kew: CAB Intl. Mycological Inst., Surrey, U.K.

Daub, M.E. and D.J. Hagedorn. 1981. Epiphytic populations of Pseudomonas syringae on susceptible and resistant bean lines. Phytopathology 71:547-550.

Duvall, K. and W.R. Krul. 1985. Identification of parameters that influence variation in root initiation of mung bean cuttings. HortScience 20:189. (Abstr.)

Dye, D.W. and W.J. Kemp. 1977. A taxonomic study of plant pathogenic Corynebacterium species. N.Z. J. Agr. Res. 20:563-582.

Fahy, P.C. and A.C. Hayward. 1983. Media and methods, p. 337378. In: P.C. Fahy and G.J. Persley (eds.). Plant bacterial diseases: A diagnostic guide. Academic, New York.

Fahy, P.C. and A.B. Lloyd. 1983. Pseudomonas: The fluorescent pseudomonades, p. 141-188. In: P.C. Fahy and G.J. Persley (eds.). Plant bacterial diseases: A diagnostic guide. Academic, New York.

Gross, D.C. and J.E. DeVay. 1977. Population dynamics and pathogenesis of Pseudomonas syringae in maize and cowpea in relation to the in vitro production of syringomycin. Phytopathology 67:475483.

Hildebrand, D. C., M.N. Schroth, and D.C. Sands. 1988. Pseudomonas, p. 60-80. In: N.W. Schaad (ed.). Laboratory guide for iden- 
tification of plant pathogenic bacteria. 2nd ed. Amer. Phytopathological Sot. Press, St. Paul, Minn.

Kado, C.I. and M.G. Heskett. 1970. Selective media for isolation of Agrobacterium, Cornyebacterium, Erwinia, Pseudomonas, and Xanthomonas. Phytopathology 60:969-976.

Kling, G.J. and M.M. Meyer. 1983. Effects of phenolic compounds and indoleacetic acid on adventitious root initiation in cuttings of Phaseolus aureus, Acer saccharinum, and Acer griseum. HortScience 18:352-354.

Kling, G. J., M.M. Meyer, and D. Seigler. 1988. Rooting cofactors in five Acer species. J. Amer. Sot. Hort. Sci. 113:252-257.

Moffett, M. L., P.C. Fahy, and D. Cartwright. 1983. Corynebacterium, p: 45-65. In: P.C. Fahy and G.J. Persley (eds.). Plant bacterial diseases: A diagnostic guide. Academic, New York.

Musgrave, M. E., W.A. Gerth, H.W. Scheld, and B.R. Strain. 1988. Growth and mitochondrial respiration of mungbeans (Phaseolus aureus Roxb.) germinated at low pressure. Plant Physiol. 86:19-22.

Norcini, J. G., C.W. Heuser, and R.H. Hamilton. 1985. Changes in free and conjugated indole-3-acetic acid during initiation and early development of adventitious roots in mung bean. J. Amer. Soc. Hort. Sci. 110:528-533.
Roy, M.A. 1988. Use of fatty acids for the identification of phytopathogenic bacteria. Plant Dis. 72:460.

Schaad, N.W. 1988. Identification schemes, p. 1-15. In: N.W. Schaad (ed.). Laboratory guide of identification of plant pathogenic bacteria. 2nd ed. Amer. Phytopathological Soc. Press, St. Paul, Minn.

Schaad, N. W., H. Azad, R.C. Peet, and N.J. Panopoulos. 1989. Identification of Pseudomonas syringae pv. phaseolicola by a DNA hybridization probe. Phytopathology 79:903-907.

Schaad, N. W., R.L. Gabrielson, and M.W. Mulanax. 1980. Hot acidified cupric acetate soaks for eradication of Xanthomonas campestris from crucifer seeds. Appl. Env. Microbiol. 39:803-807.

Tripepi, R. R., C.W. Heuser, and J.C. Shannon. 1983. Incorporation of tritiated thymidine and uridine into adventitious-root initial cells of Vigna radiata. J. Amer. Soc. Hort. Sci. 108:469474.

Vivader, A.K. and M.J. Davis. 1988. Coryneform plant pathogens, p. 104-113. In: N.W. Schaad (ed.). Laboratory guide for identification of plant pathogenic bacteria. 2nd ed. Amer. Phytopathological Soc. Press, St. Paul, Minn.

Zaumeyer, W.J. and H.R. Thomas. 1957. A mononographic study of bean diseases and methods for their control. U.S. Dept. Agr. Tech. Bul. 868. 